\title{
BIOBRIKET ENCENG GONDOK (EICHHORNIA CRASSIPES) SEBAGAI BAHAN BAKAR ENERGI TERBARUKAN
}

\author{
Muhammad Arief Karim, Eko Ariyanto"), dan Agung Firmansyah \\ Program Studi Teknik Kimia, Universitas Muhammadiyah Palembang \\ Jln. A. Yani 13 Ulu Palembang, 30263, Indonesia, Telp. (0711)510820 \\ ${ }^{*}$ Penulis Korespondensi: ekochemump2002@yahoo.com
}

\begin{abstract}
WATER HYACINTH (EICHHORNIA CRASSIPES) BIOBRIQUETES AS RENEWABLE ENERGY SOURCE. Depletion of fossil energy reserves as a result of increased population growth and industrial sectors. Biomass can be considered as the best option for alternative renewable energy. The objective of this study was to investigate the possibility of water hyacinth (Eichhornia crassipes) to produce bio-briquette. The briquetting experiment was conducted with different both of tapioca strach and wood glue adhesive. The presentage of adhesive was 4\%, 6\%, 8\%, 10\%, and 12\%. The briquettes were tested to evalueted water content, ash content and calorific value. The results showed that the value of water content and ash content increased by increasing presentage adhesive on biobriquete. However, the calorific value reached the maximum point of $10 \%$ and $8 \%$ for addition tapioca strach and wood glue adhesive, respectively.
\end{abstract}

Keywords: biobriquetes; renewable energy; water hyacinth

\begin{abstract}
Abstrak
Menipisnya cadangan energi fosil sebagai akibat dari meningkatnya pertumbuhan penduduk dan sektor industri. Biomassa dapat dianggap sebagai pilihan terbaik untuk energy alternatif terbarukan. Tujuan dari penelitian ini adalah untuk mengamati kemungkinan eceng gondok (Eichhornia crassipes) untuk diolah menjadi bio-briket. Penelitian briket dilakukan dengan menggunakan tepung tapioka dan lem kayu sebagai perekat. Dengan persentase perekat adalah 4\%, 6\%, 8\%, 10\%, dan 12\%. Bio-briket yang dihasilkan diamati kadar air evalueted, kadar abu dan nilai kalor. Hasil penelitian menunjukkan bahwa nilai kadar air dan kadar abu meningkat dengan meningkatnya presentasi perekat pada biobriket. Namun, nilai kalor mencapai titik maksimum 10\% dan 8\% untuk masing-masing penambahan tapioka strach dan lem kayu perekat.
\end{abstract}

Kata kunci: biobriket; energi terbarukan; eceng gondok

How to Cite This Article: Karim, M.A., Ariyanto, E., dan Firmansyah, A., (2014), Biobriket Enceng Gondok (Eichhornia Crassipes) Sebagai Bahan Bakar Energi Terbarukan, Reaktor, 15(1), 59-63, http://dx.doi.org/ 10.14710/reaktor.15.1.59-63

\section{PENDAHULUAN}

Pemanfaatan sumber energi fosil yang berlebihan dapat mengakibatkan semakin menipisnya ketersediaan sumber energi tersebut. Ketergantungan Indonesia pada energi fosil membuat produksi minyak bumi menurun drastis. Keadaan ini didorong oleh peningkatan dan pertumbuhan sektor industri dan penduduk. Menipisnya cadangan energi fosil harus segera diimbangi dengan penyediaan energi alternatif yang dapat diperbaharui, melimpah jumlahnya, dan murah harganya sehingga terjangkau oleh masyarakat luas (Elfiano dkk., 2014).

Berbagai solusi telah dilakukan oleh para ilmuan untuk mengatasi ketergantungan terhadap sumber energi tak terbarukan. Diantara berbagai solusi tersebut adalah dengan memanfaatkan energi terbarukan seperti biomassa. Energi biomassa dengan metode pembriketan adalah mengkonversi bahan baku padat menjadi suatu bentuk hasil kompaksi yang lebih mudah untuk digunakan (Husada, 2008). Penggunaan biobriket sebagai bahan bakar merupakan salah satu solusi alternatif untuk menghemat pemakaian bahan bakar fosil dan dalam penggunaan secara berkelanjutan dapat mengurangi dampak emisi karbon (Saputata dkk., 2013).

Sumber bahan baku biobriket dari bahan hayati adalah kulit kopi (Suarez dan Luengo 2003), ampas tebu dan kayu (Elfiano dkk., 2014), dan tongkol 
jagung (Sinurat, 2011). Butiran halus bioarang dari hasil karbonisasi bahan hayati membutuhkan perekat sehingga biobriket tidak mudah hancur. Jenis perekat berpengaruh terhadap kadar air, kadar abu dan nilai kalor. Kadar air semakin rendah jika jumlah bioarang semakin banyak (Ndraha, 2009).

Terdapat dua golongan perekat dalam pembuatan biobriket, yaitu perekat yang berasap (tar, pitch, clay, dan molases) dan perekat yang kurang berasap (pati, dekstrin, dan tepung beras) (Saleh, 2013). Pemakaian tar, pitch, clay, dan molases sebagai bahan perekat menghasilkan biobriket yang berkekuatan tinggi tetapi mengeluarkan banyak asap jika dibakar yang disebabkan adanya komponen yang mudah menguap. Bahan perekat pati, dekstrin, dan tepung beras akan menghasilkan biobriket yang tidak berasap dan tahan lama tetapi nilai kalornya tidak tinggi. Bahan perekat dari tumbuh-tumbuhan seperti pati (tapioka) memiliki keuntungan dimana jumlah perekat yang dibutuhkan untuk jenis ini jauh lebih sedikit dibandingkan dengan bahan perekat hidrokarbon (Saleh, 2013). Bahan perekat tapioka memiliki kelemahan yaitu sifatnya dapat menyerap air dari udara sehingga tidak baik apabila berada dalam kelembaban udara yang tinggi. Karakteristik bahan baku perekat untuk pembuatan biobriket adalah memiliki gaya kohesi yang baik bila dicampurkan dengan bioarang, mudah terbakar, tidak berasap, mudah didapat dalam jumlah banyak dan murah harganya dan tidak mengeluarkan bau, tidak beracun dan tidak berbahaya (Fachry dkk., 2010).

Jenis perekat yang digunakan adalah salah satu faktor penting yang harus dipertimbangkan saat pembriketan dengan tujuan agar biobriket akan melepaskan panas maksimum. Dan tujuan pembuatan biobriket adalah untuk menghasilkan sumber bahan bakar yang baik dan efisien energi yang tinggi maka penggunaan persentase bahan perekat adalah salah satu campuran yang harus dipertimbangkan.

Beberapa hasil penelitian nilai kalor biobriket dari berbagai media antara lain eceng gondok (2785 kal/g) (Supatata dkk., 2013) dan serbuk kayu (4820 $\mathrm{kal} / \mathrm{g}$ ) (Akowuah dkk., 2012).

Pada penelitian ini, eceng gondok dipilih sebagai bahan biomassa yang kemudian dibuat menjadi biobriket bioarang. Eceng gondok (Eichhornia crassipes) adalah salah satu jenis tumbuhan air mengapung. Eceng gondok memiliki kecepatan tumbuh yang tinggi sehingga tumbuhan ini dianggap sebagai gulma yang merusak lingkungan perairan. Eceng gondok dengan mudah menyebar melalui saluran air ke badan air lainnya. Pertumbuhan eceng gondok yang cepat terutama disebabkan oleh air yang mengandung nutrien yang tinggi, terutama yang kaya akan nitrogen, fosfat dan potassium. Analisa nilai kalor, kandungan air dan sulfur dilakukan pada biobriket eceng gondok ini untuk mengetahui karakteristik pembakaran sehingga biobriket ini berpotensi untuk dimanfaatkan sebagai bahan bakar alternatif.

\section{METODE PENELITIAN \\ Bahan Penelitian}

Bahan penelitian ini berupa eceng yang didapatkan di Sungai Musi Palembang, Ssumatera Selatan. Bahan perekat terdiri dari tepung tapioka dan lem kayu. Tepung tapioka diperoleh dari pasaran dengan spesifikasi moisture (max. 14,3), protein (11,0-12,5\%), abu (max. 0,64\%) dan Gluten Wet (min 26,5\%). Jenis lem kayu yang digunakan adalah jenis lem Epoxy.

\section{Proses Pengolahan Bahan Menjadi Arang}

Enceng gondok dibersihkan dari kotoran yang terbawa dengan dicuci menggunakan air bersih. Eceng gondok yang telah dipotong kecil-kecil $( \pm 3 \mathrm{~cm})$ dikeringkan di bawah sinar matahari selama 2 hari untuk mengurangi kadar air. Proses pengarangan enceng gondok menggunakan furnace dengan suhu $400^{\circ} \mathrm{C}$ selama 1 jam. Setelah dikeluarkan dari dalam furnace, lalu arang bioarang enceng gondok dihaluskan lalu dan diayak ukuran 35 mesh.

\section{Proses Pencampuran Arang dengan Perekat}

Bioarang dari proses karbonasi digiling atau dihaluskan dan diayak kemudian ditambahkan perekat yang telah disiapkan dengan perbandingan 4, 6, 8, 10, dan $12 \%$ bagian perekat dari berat arang dan diaduk hingga semuanya tercampur secara merata. Beri label pada tiap campuran sesuai perlakuan.

\section{Proses Pencetakan Biobriket}

Dimasukkan bahan biobriket yang sudah dicampur ke dalam alat pencetak biobriket. Biobriket dikeringkan dengan oven pada suhu $80^{\circ} \mathrm{C}$ selama \pm 10 jam. Biobiobriket dikeluarkan dari dalam oven dan dibiarkan sampai dingin. Dan biobiobriket yang dihasilkan kemudian diuji kualitas.

\section{HASIL DAN PEMBAHASAN Analisa Kadar Air}

Kadar air menentukan kualitas biobriket dan karakteristik pembakaran. Semakin tinggi kadar air, maka semakin sulit biobriket tersebut terbakar. Tingkat kadar air membantu dalam proses penyimpanan dimana untuk mencegah terjadinya proses kelembaban. Menurut Misha dan Grover (1996) presentase kadar air yang sesuai dengan standard adalah 10-15\%. Dalam kisaran tersebut biobriket lebih stabil dan tahan lama.

Dari hasil pengujian yang ditunjukkan pada Gambar 1 kadar air yang terdapat pada biobriket enceng gondok berbanding lurus dengan penambahan perekat yang dilakukan, dimana semakin banyak perekat yang dicampurkan pada biobriket maka semakin tinggi kadar air yang dimiliki oleh biobriket tersebut. Dari data hasil pada Gambar 1 menunjukkan bahwa kandungan air dari biobriket dengan campuran perekat tapioka adalah antara 3,24-5,45\% dan lem kayu antara 2,94-5,03\%. Biobriket dengan persentase perekat terendah yaitu $4 \%$ memiliki kadar air paling 
sedikit yaitu 2,9\% untuk perekat lem kayu dan 3,24\% untuk perekat tapioka. Sehingga dapat disimpulkan bahwa perekat memberi pengaruh yang berarti terhadap kadar air yang terkandung dalam biobriket.

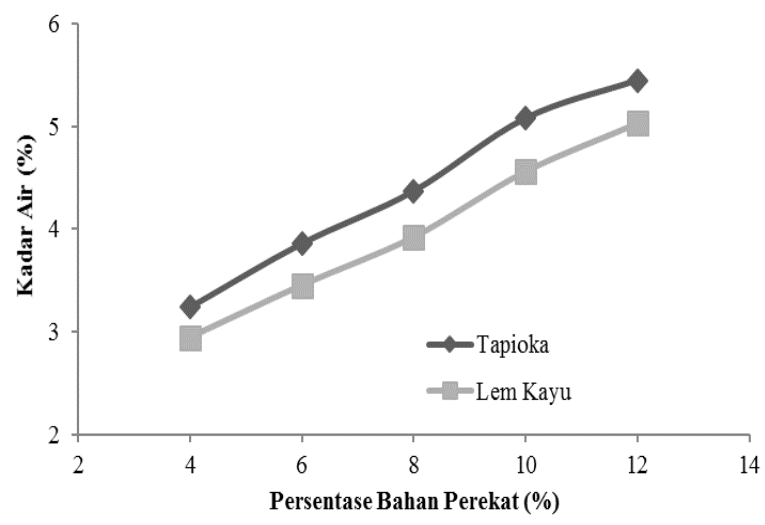

Gambar 1. Pengaruh jumlah perekat terhadap \% kadar air

Pengaruh jenis perekat terhadap kadar air dapat dilihat pada Gambar 1. Dari Gambar 1 terlihat kadar air tertinggi terdapat pada perekat dari tapioka. Kadar air yang besar ini disebabkan karena adanya ikatan kimia air di dalam tapioka. Kadar air tertinggi pada $5,45 \%$ pada jenis perekat tepung tapioka dengan jumlah perekat $12 \%$ sedangkan kadar air terendah sebesar 2,94\% terdapat pada jenis perekat dari lem kayu dengan jumlah perekat 4\%. Faktor lain adalah pada pencampuran dengan menggunakan lem kayu menghasilkan biobriket yang kurang berpori sehingga tidak mudah air dilepaskan pada waktu pengeringan. Dengan kadar air yang tinggi dalam biobriket, memerlukan panas yang tinggi untuk menguapkan air dan kadang-kadang briket terbelah menjadi potonganpotongan kecil pada tingkat pembakaran rendah dan sehingga lebih sedikit panas yang dihasilkan oleh pembakaran biobriket dansebagai akibatnya asap yang dihasilkan akan banyak (Akowuah dkk., 2012).

\section{Analisa Kadar Abu}

Kadar abu adalah persentase dari zat-zat yang tersisa dari proses pembakaran dan sudah tidak memiliki unsur karbon. Semakin tinggi kadar abu dalam suatu biobriket maka kualitas biobriket akan semakin rendah, karena kandungan abu yang tinggi dapat menurunkan nilai kalor dari biobriket. Dari Gambar 2 dapat dilihat pengaruh jumlah perekat terhadap nilai kadar abu dari biobriket hasil penelitian.

Pada Gambar 2 menunjukkan bahwa penambahan tapioka sebagai perekat menghasilkan kadar abu yang tinggi dibandingkan menggunakan perekat lem kayu. Kadar abu biobriket arang enceng gondok tertinggi adalah $8,03 \%$ pada jenis perekat $12 \%$ tapioka dan kadar abu terendah 4,17\% pada jenis perekat 4\% lem kayu. Tingginya kadar abu pada perekat tapioka disebabkan karena tapioka memiliki molekul karbohidrat, amilosa, dan amilopektin, yang terdiri dari unsur karbon, hidrogen, dan oksigen, sehingga strukturnya mudah berubah menjadi abu setelah proses pembakaran. Kadar abu adalah komponen biomassa yang tidak mudah terbakar dan mempengaruhi proses transfer panas ke permukaan biobriket dan juga difusi oksigen ke permukaan biobriket selama proses pembakaran (Katimbo dkk., 2014). Kadar abu yang tinggi menghasil emisi debu yang dapat menyebabkan polusi udara dan mempengaruhi volume pembakaran dan efisiensi. Semakin tinggi kadar abu biobriket, semakin rendah nilai kalori dan mempengaruhi laju pembakaran karena rendahnya transfer panas ke bagian dalam biobriket dan difusi oksigen ke permukaan briket arang selama pembakaran.

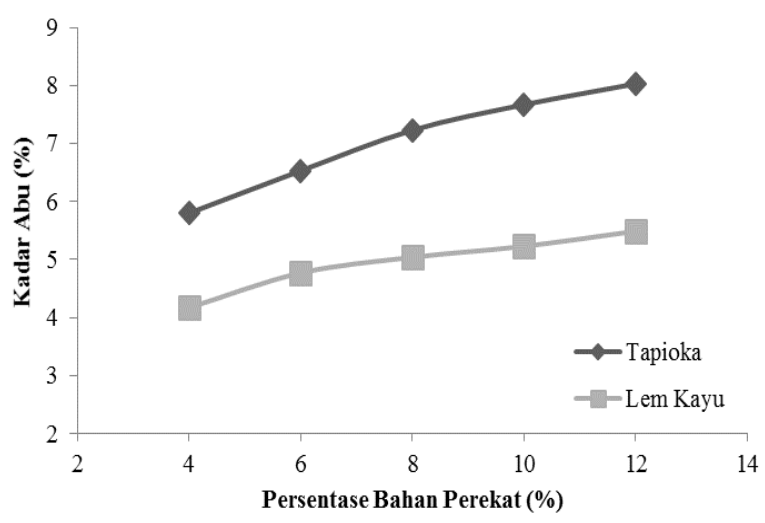

Gambar 2. Pengaruh jumlah perekat terhadap \% kadar abu.

Menurut Standar Nasional Indonesia mensyaratkan kadar abu maksimal tidak melebihi $5,51 \%$ tetapi pada biobriket enceng gondok yang memenuhi hanya campuran perekat lem kayu 4\% dengan nilai 4,17\%, 6\% dengan nilai 4,77\% dan $8 \%$ dengan nilai 5,04\%. Sedangkan campuran perekat tepung tapioka melebihi kadar maksimal abu yang ditetakan.

\section{Analisa Nilai Kalor}

Dari Gambar 3 didapat nilai kalor biobriket arang enceng gondok yang tertinggi dengan jenis perekat lem kayu dengan jumlah perekat $8 \%$ yaitu sebesar 4341,67cal/g. Nilai kalor terendah pada jenis perekat tapioka dengan jumlah perekat 4\% yaitu 4238,67 cal/g.

Dari Gambar 3 dapat dilihat bahwa jenis perekat dan jumlah perekat sangat mempengaruhi nilai kalor biobriket. Penambahan perekat lem kayu 8\% mencapai titik maksimum nilai kalor biobriket yang mencapai 4341,67 cal/g dan 10\% menggunakan perekat tapioka yang mencapai titik maksimum nilai kalor 4299,33 cal/g. Pencapaian titik maksimum nilai kalor dikarenakan kepadatan biobriket mencapai titik maksimum sehingga menghasilkan penurunan density biobriket dan menurunkan nilai kalor (Islam dkk., 2014). 


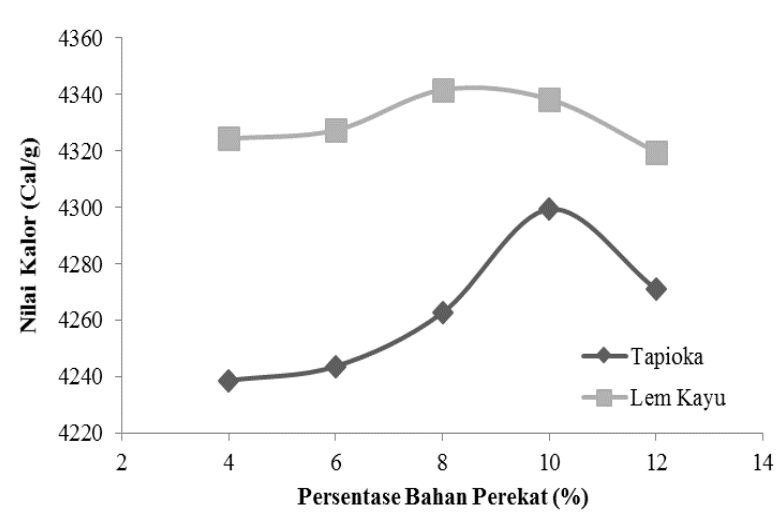

Gambar 3. Pengaruh jumlah perekat (\%) terhadap nilai kalor (cal/gr) dalam berbagai jenis perekat

Jenis perekat lem kayu tidak terlalu banyak mengandung air sehingga nilai karbon dari biobriket tersebut besar. Nilai karbon yang besar menyebabkan besarnya nilai kalor dari suatu biobriket. Sedangkan pembuatan biobriket yang menggunakan jenis perekat dari tapioka mengandung banyak air sehingga kandungan air ini mempengaruhi kecilnya nilai kalor yang dihasilkan. Dengan rendahnya kadar air, maka kalor yang ditentukan untuk menguapkan air juga sedikit, sehingga energi kalor yang tersisa pada biobriket akan semakin besar.

\section{Analisa Karakteristik}

Karakteristik biobriket eceng gondok dapat dilihat pada Gambar 4. Struktur morfologi biobriket dari berbagai perekat yang digunakan yang dianalisa menggunakan Scanning Elektron Microscope pada 25 kv. Struktur morfologi biobriket dengan menggunakan perekat lem kayu pada 8\% (Gambar 4a) menunjukkan struktur berserat dan kasar yang beragam, sedangkan biobriket menggunakan perekat tapioka (Gambar 4b) menunjukkan massa struktur serat yang longgar.

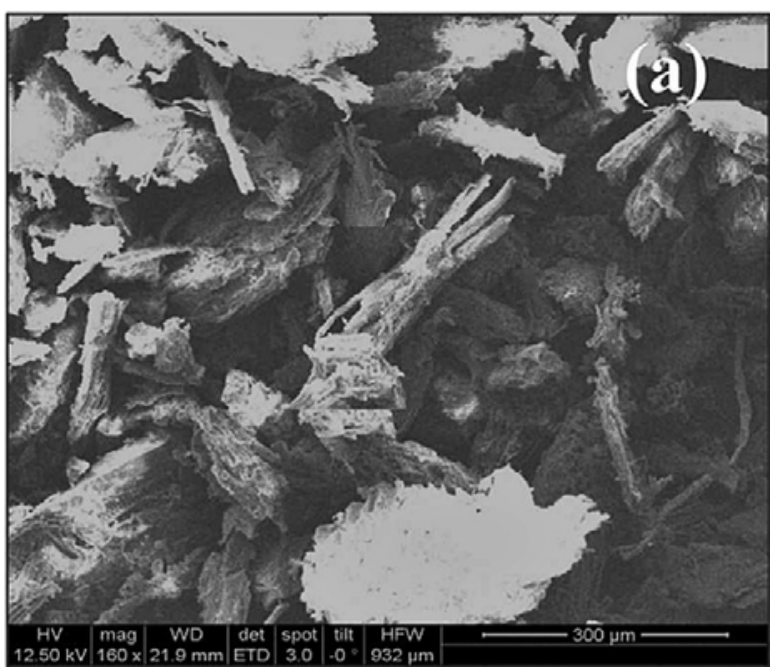

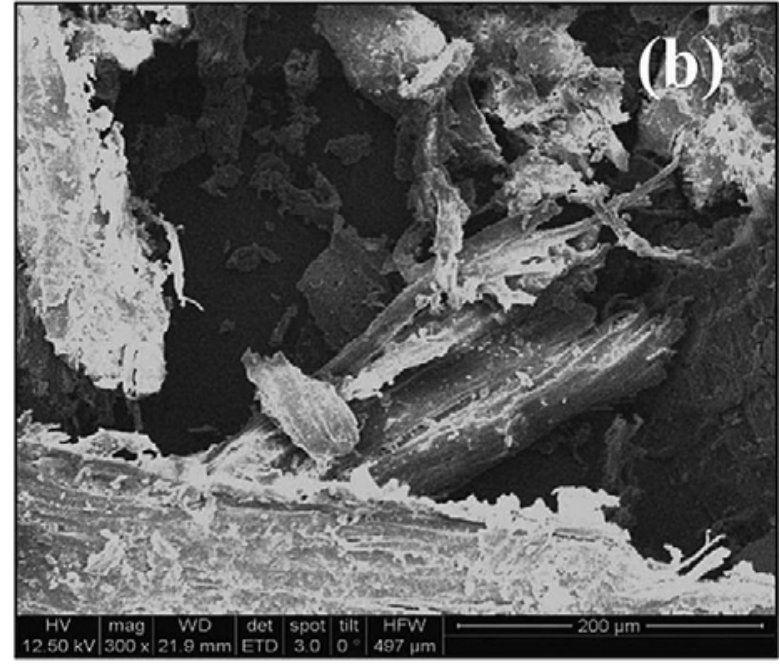

Gambar 4. Analisa Biobriket dengan SEM. (a) Perekat Lem Kayu; (b) Perekat Tapioka

\section{KESIMPULAN}

Hasil penelitian dan pengujian biobriket eceng gondok terhadap jenis perekat yang digunakan dapat disimpulkan bahwa pengaruh bahan perekat dan komposisinya memberi pengaruh yang sangat siginifikan terhadap kadar air, kadar abu dan nilai kalor yang dihasilkan.

Kadar air tertinggi pada jenis perekat tepung tapioka dengan jumlah perekat $12 \%$ sedangkan kadar air terendah terdapat pada jenis perekat dari lem kayu dengan jumlah perekat 4\%. Tingginya kadar air pada perekat tapioka disebabkan adanya ikatan kimia air di dalam tapioka.

Kadar abu biobriket arang enceng gondok tertinggi adalah pada jenis perekat tepung tapioca. Tingginya kadar abu pada perekat tapioka disebabkan adanya molekul kimia yang dapat berubah menjadi abu pada saat pembakaran seperti molekul karbohidrat, amilosa, dan amilopektin, yang terdiri dari unsur karbon, hidrogen, dan oksigen, sehingga strukturnya mudah berubah menjadi abu setelah proses pembakaran.

Penambahan perekat lem kayu 8\% mencapai nilai maksimum kalor biobriket yang dihasilkan dan 10\% menggunakan perekat tapioka. Pencapaian titik maksimum nilai kalor dikarenakan kepadatan biobriket mencapai titik maksimum sehingga menghasilkan penurunan density biobriket dan menurunkan nilai kalor.

Pembuatan biobriket arang enceng gondok mampu meningkatkan nilai kalor arang enceng gondok yang hanya $3300 \mathrm{cal} /$ gr menjadi 4341cal/gr, namun belum mampu mencapai nilai kalor seperti biobriket batubara dengan nilai kalor mencapai 6000 $\mathrm{cal} / \mathrm{gr}$.

\section{DAFTAR PUSTAKA}

Akowuah, J.O., Kemausuor, F., and Mitchual, S.J., (2012), Physico-Chemical Characteristics and Market 
Potential of Sawdust Charcoal Briquette, International Journal of Energy and Environmental Engineering, 3(20), pp. 1-6.

Elfiano, E., Natsir, M., and Indra, D., (2014), Analisa Proksimat Briket Bioarang Campuran Limbah Ampas Tebu Dan Arang Kayu, Seminar Nasional Teknik Mesin Universitas Trisakti, 1-6, Vol.KE14, ISBN:978602-70012-0-6

Fachry, A.R., Sari, T.I., Dipura, A.Y., and Najamudin, J., (2010), Teknik Pembuatan Briket Campuran Eceng Gondok dan Batubara sebagai Bahan Bakar Alternatif bagi Masyarakat Pedesaan, Seminar Nasional Perkembangan Riset dan Teknologi ke 16, Jakarta. 5258, Vol.16, ISBN:978-979-95620-6-7

Husada, T.I. (2008), Arang Briket Tongkol Jagung Sebagai Energi Alternatif, Laporan Hasil Penelitian Program Inovasi Mahasiswa Provinsi Jawa Tengah, Universitas Negeri Surakarta, Semarang.

Islam, M.H., Hossain, M.M., and Momin, M.A., (2014), Development of Briquette from Coir Dust and Rice Husk Blend: An Alternative Energy Source, International Journal of Renewable Energy Development, 3(2), pp. 119-123.

Katimbo, A., Kiggundu, N., Kizito, S., Kivumbi, H.B., and Tumutegyereize, P., (2014), Potential of Densification of Mango Waste and Effect of Binders on Produced Briquettes, Agricultural Engineering International: CIGR Journal, 16(4), pp.146-155.

Mishra, S.K. and Grover, P.D., (1996), Biomass Briquetting: Technology and Practices, Bangkok, Food And Agriculture Organization Of The United Nations.

Ndraha, N., (2009), Uji Komposisi Bahan Pembuat Briket Bioarang Tempurung Kelapa dan Serbuk Kayu Terhadap Mutu yang Dihasilkan, Universitas Sumatera Utara.

Saleh, A., (2013), Efisiensi Konsentrasi Perekat Tepung Tapioka Terhadap Nilai Kalor Pembakaran Pada Biobriket Batang Jagung (Zea Mays L.), Jurnal Teknosains, 7(1), pp. 78-89.

Sinurat, E., (2011), Studi Pemanfaatan Briket Kulit Jambu Mete Dan Tongkol Jagung Sebagai Bahan Bakar Alternatif, Universitas Hasanuddin.

Suarez, J.A. and Luengo, C.A., (2003), Coffee Husk Briquettes: A New Renewable Energy Source, Energy Sources, 25(10), pp. 961-967.

Supatata, N., Buates, J., and Hariyanont, P., (2013), Characterization of Fuel Briquettes Made from Sewage Sludge Mixed with Water Hyacinth and Sewage Sludge Mixed with Sedge, International Journal of Environmental Science and Development, 4(2), pp. 179-181. 